\title{
Mind Mapping Methods Using to Improve Student Learning Outcomes of Social Studies Learning in Class VII-F 7 Bandung Junior High School
}

\author{
(Classroom Action Research at Class VII-F 7 Bandung Junior High School)
}

\author{
Budi Nur Faisal * \\ budi.nur.faisal@student.upi.edu \\ Indonesia University of Education
}

\author{
Prof. Dr. Kokom Komalasari M.Pd \\ Dr. Neinny Ratmaningsih M.Pd.
}

\begin{abstract}
This research is motivated by the problems that researchers find in the learning process of social studies related to the low student learning outcomes. The issues raised in this study about improving student learning outcomes through the use of mind mapping method in social studies learning. Learning outcomes are characterized by changes in behavior. While Mind Mapping is a way of recording a creative and effective, easy way to enter and release information in the brain that suits the workings of the brain. So mind mapping can be an alternative method to improve student learning outcomes. This study aims to describe how planning, implementation, results, and efforts to overcome obstacles in an effort to improve student learning outcomes through mind mapping method in social studies learning in class VII-F 7 Bandung Junior High School. The research method used is classroom action research with Kemmis \& Taggart design. The source of this research data is the improvement of learning outcomes through the use of mind mapping method in social studies learning. Indicator of learning outcomes in this study is to remember, understand, apply, create, and Attitudes. In the indicators of understand and remember there is an increase in each cycle. In addition to the improvement of the post test results in each cycle. The general conclusion is the use of mind mapping method can improve students' learning outcomes in social studies learning at class VII-F
\end{abstract}

Keywords: Learning Outcomes in Social Studies, Mind Mapping.

\section{INTRODUCTION}

Based on observations made by researchers on January 25, 2017 at class VII-F in 7 Bandung Junior High Shool at Jalan Ambon No. 23, Citarum Bandung, social studies learning conducted in the classroom is still not in accordance with what is expected from the social studies goal. Empirical observations conducted by researchers at class VII-F found some problems during the learning process among others, firstly when the teacher entered into the class, the students were asked to present the assignment given before but in each group, the students who presented seemed to have difficulties in understanding the material displayed. Secondly, when the group did a presentation some groups were less concerned and there were even students who had used cell phones during the learning process. thirdly, when the teacher asks questions or give opportunities to ask there are only a few students who ask and only students who are active and always ask in a particular group. Fourth, some students are have less skill to write and compose the material concepts of the lessons presented by the teacher. Fifth, the tendency of teachers to use the Internet network as a source of learning after textbooks, affects the students' short understanding and resulted in the low memory student's on the social studies material.

Based on the observations by researchers, it is known that the cause of the above problems leads to a learning strategy that is still oriented to mastery of the material by assigning students to seek information about social studies materials that make the Internet as a source of learning in the classroom. The use of such learning strategies has little impact on the material understanding on the students. Rapid information as a feature of the internet, impacts on students' ability to construct information. The problem is important and urgent to be resolved, because if there is no way to solve it will have an impact on the less effective social studies classroom learning process. Therefore, it is necessary to change the learning model so can to improve learning outcomes. One of the alternative learning model is the use of Mind Mapping method in the learning process.

One method that is considered appropriate to be applied in this learning is using Mind Mapping. The use of Mind Mapping is proposed to solve problems in class VII-F. The Mind Mapping model is closely related to the function of the mind, and the Mind Map can be used in almost every activity that involves the mind, recall, plan, or creativity, Buzan (2006, pp. 143). The use of Mind Mapping methods is expected to increase student outcomes learning. Because learning directly involving students will be easy to understand. 'The mind map can be done in the retrieval of information in the mind faster by listening to the mind map made', Putra (2008, p 258). Activity learning by involving students play an active role in learning and using the abilities contained in his mind and then poured in the form of a map of thought (Mind Mapping) will help students remember more powerful material, because the notes are made by students themselves and can improve on improving student learning outcomes.

The formulation of problems made based on the above background, among : first, How to plan Mind mapping method in improving student learning outcomes in social studies learning. Second How to implement Mind Mapping method in improving student learning outcomes. Third How student learning outcomes on social studies subjects by applying Mind Mapping method. Fourth, how the constraints and efforts by teachers to solve obstacles in applying Mind Mapping method.

\section{RESEARCH METHODS}

The research method used in this research is classroom action research method with research design refers to model 
developed by Kemmis and Mc Taggart. This research method using qualitative research method according to (Bogdan and Biklen, 1982) states that qualitative research is done on natural condition in the sense that research is done directly to data source, qualitative research is more descriptive, accumulated in the form of words or images so is not to emphasize the numbers, qualitative research more emphasis on the process than the results, qualitative research conducted inductive data analysis and qualitative research is more emphasis on meaning. This study is based on a problem that occurs in the classroom. Then done by the researchers themselves who simultaneously play as a teacher and focus on one class that has problems about the low student learning outcomes. Improvement of student learning outcomes is done to improve the learning process. Especially in Social Studies. This is in line with the purpose of Classroom Action Research.

In this research, researchers used several data collection techniques namely, observation, tests, field notes and documentation during the research took place. This qualitative data analysis is conducted simultaneously with the data collection process. Analysis of the data consists of several components of activities that are interconnected with each other, This data reduction process starts from the initial study to the end. This process through stages of sharpening, focusing, unrelated data allowance Quantitative data analysis used to analyze data to determine the success of student learning outcomes that refer to the test results given. The test results are then calculated through quantitative data analysis, ie by finding the average value. The data analysis used by researchers refers to Komalasari (2011, p. 156) as follows:

$$
\text { Score Result: } \quad \text { : } \quad \frac{\text { Score obtained }}{\text { maxium score }} \times 100 \%
$$

\section{RESULTS AND DISCUSSION}

Planning start by making initial observations or preresearch to knowing initial conditions of learning as a preliminary picture. Then based on these results, researchers found various problems that lead to student learning outcomes. After knowing the problem, the researcher started to formulate the appropriate indicator and the development of learning planning using Mind Mapping method as an effort to improve student learning outcomes in the class that become the research subject, that is VII-F.

In the first cycle the teacher explained what is meant of the Mind Mapping concept. This should be done so that the learning process social studies runs well. Mind Mapping is not only used as a method, but is attempted as a learning resource, as described by Banks (in Komalasari, 2011. pp. 108) that learning resources are 'everything or power that teachers can use, either separately or in combination, to the importance of teaching and learning with the aim to improve the effectiveness and efficiency of learning objectives In the second cycle of learning implementation using Mind Mapping method held two meetings. This is based on the results of reflection and consideration on the material being taught. In the first compilation the teacher manually draws Mind Mapping about pre-script material. Then for reinforcement and variation in teacher learning activities displaying videos relating to pre-script material after the teacher's presentation correlates the essence of the video playback with the Mind Mapping that has been drawn. Then the teacher gives the student worksheet, the teacher asks the whole group to work on the worksheet. Here are the Mind Mapping that teachers use:

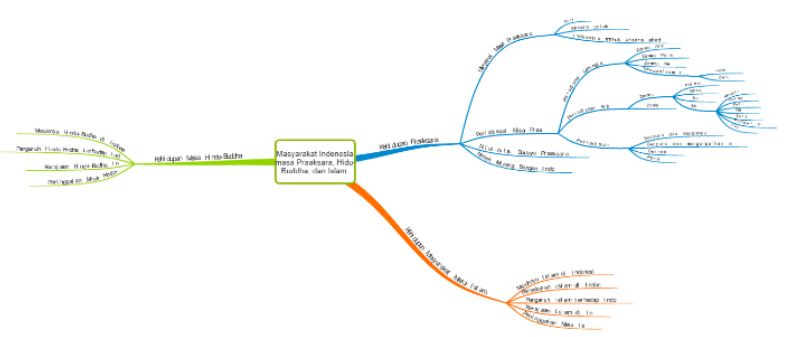

In the third cycle, conducted with two meetings, the material raised is about the entry of Hindu-Buddhist culture in Indonesian society, the theme of the material focuses on the theory of the entry of Hindu-Buddhist culture, as well as the various influences discussed in outline. Furthermore, the teacher gives the student worksheet integrated with the indicator of Learning Outcomes, different thing in the third cycle is the teacher directs the students to make Mind Mapping with similar pattern.

Implementation of measures to improve student learning outcomes of class VII-F through the use of Mind Mapping method in social studies learning. It's done in three cycles. Implementation of the activity begins with the apperception done by the teacher, then deliver the material first and publish video related to the role of science and technology in human life. The activity continued with the introduction of Mind Mapping by the teacher, at the time of the introduction of some students have heard and know the concept of Mind Mapping. First, the students' difficulties in recalling the various words of the concept on learning materials social studies. That's because the ability to understand and remember is still low. The purpose of Mind Mapping is to mapping the abstract words into meaningful and memorable, Porter (2011. p. 154). Secondly, the students 'skill in understanding the relationship between the concept of the subject in the social studies lesson, the linear tendency of students' writing makes it difficult for students to understand the recorded material, so that there is no meaning in the learning process, Buzan (2009, pp. 36) Third, less attention teachers, some students tend not to focus on learning and distracted and out on the context of learning This resulted in other students diverted due to other students who are not conducive. Implementation The second cycle was conducted in two meetings, In the first meeting the teacher delivered the material delivered by Mind Mapping manually by the teacher on the blackboard. Improved learning outcomes in this cycle began to increase, first, the students better understand the steps of making Mind Mapping. The shapes and patterns used are more diverse, the use of color and summarizes the form of matter into Mind Mapping is better than the previous cycle. Second, students are more active when other groups display Mind Mapping results. Some students respond with some questions such as why color usage is used. In this third cycle students experience a re-increase in learning outcomes. Among them are: First, students can make 
Mind Mapping, with teacher's instructed pattern this is seen from Mind Mapping result that has been made. Second, the explanation and presentation of the material at the time of presentation is better and the students actively respond to the presentation. Third, some students are not disturbing by the mobile phone they carry, the students are able to focus and enjoy the learning process.There is assessment of post test results in learning using Mind Mapping method to improve student learning outcomes in learning, as follows:

\section{Average Value Comparison of Post Test Results}

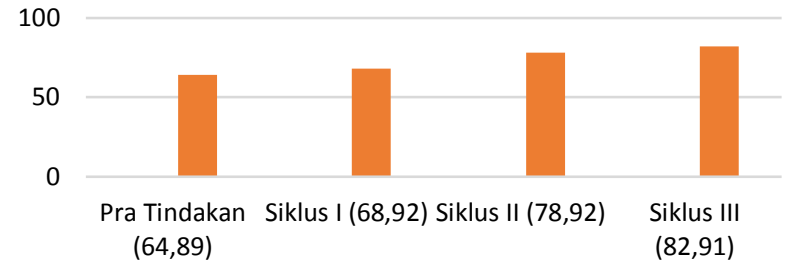

Based on the graph, learning outcomes in the form of post test result in the first cycle has almost doubled, from the initial percentage of $18.42 \%$, so that in the first cycle obtained the percentage of student learning outcomes of $31.57 \%$. This shows that the action in cycle I has an effect on the improvement of learning outcomes of social studies at class VII F. Students who have reached minimum score are 12 students, while 26 students have not reached minimum score. The average value obtained by students in cycle $\mathrm{I}$ is equal to 68.92. However, the improvements made in cycle I still can not be said to be successful. This is because the percentage of student achievement reaching Minimum score $(\geq 75)$ has not reached $75 \%$. In addition, the results of observations that have been processed researchers on the application of mind mapping methods to improve student learning outcomes obtained graphic results as follows:

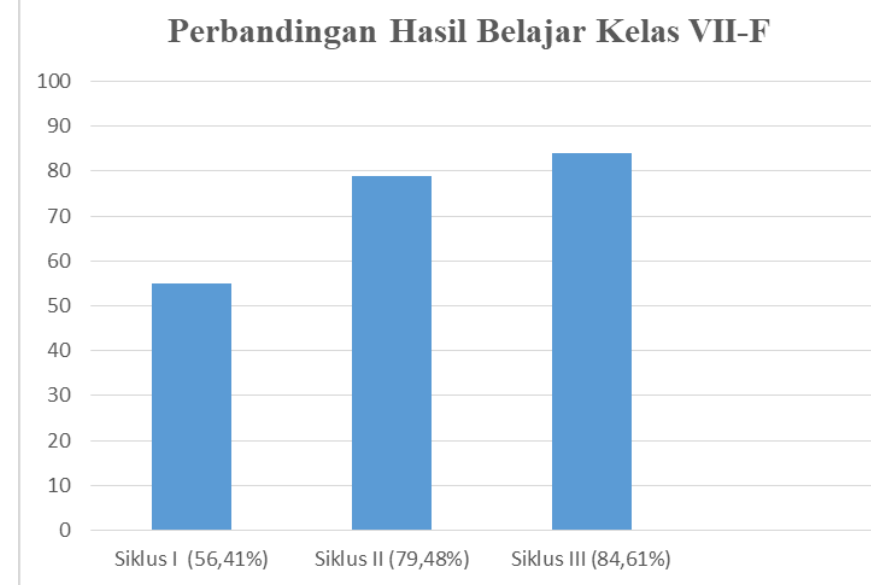

the implementation of social studies learning with the application of Mind Mapping method has been very good. It can be seen from the increase of observation result on the implementation of learning that is in cycle I obtained score 56,41 and in cycle II to 79,48 and continue to increase in Cycle III become 84,61. This result according to Arikunto (2010.hlm.56) including good category. During the research conducted researchers found some obstacles gained during the research process took place, the constraints are influential in the process and the results of research. Obstacles experienced by researchers both from the teacher and students as an effort to improve student learning outcomes through the use of mind mapping method in social studies learning in class VII-F. Obstacles experienced by teachers when using the Mind Mapping method is, first, the planned time allocation is not perfect. Second, researchers find it difficult to provide reinforcement and give direction to students if there is a lack of understanding. Third, appreciation for the students is not fullness.

\section{CONCLUDE}

First, Planning using Mind Mapping method to improve student learning outcomes on social studies learning is well planned. the planning is done with suggestions by researchers who play the role of teachers. In the first cycle Learning is prepared to improve the ability to remember for improve student learning outcomes is to provide learning that can analyze and mapping the problem and social issues and seek links between the concepts therein. The researcher prepares the lesson plan with the Competency Standards. Prepares the lesson material and seeks references from various textbooks and the internet so that the material can be presented well. In addition to looking for problems related to the material and daily life of students. So it can determine the right theme to implement mind mapping. Learning materials to be delivered in the first cycle is about the role of science and technology in the economic activities of distribution, consumption, and production and then in each cycle researchers measure the success rate of students by giving a question of post test results. in the second and third cycles the planning is based on observer observations, documentation and student activity sheets and teachers to plan better action scenarios to overcome the shortcomings obtained based on reflection results at each end of the cycle.

Secondly, during the learning process using Mind Mapping method gets good response from students indicating that the implementation is going well. In the first cycle researchers explain how to create Mind Mapping and connectedness with social studies learning materials. After the teacher exposes the material using Mind Mapping students are assigned to create Mind Mapping in accordance with the material taught in each cycle. Then at each finish cycle students do post-test questions to measure the success rate of learning outcomes this is done starting from the first cycle until the third cycle.

Third, as for the improvement of student learning outcomes after the application of mind mapping method from cycle I to cycle III has a good improvement. In the first cycle students get the category pretty good because there are still many things that need to be improved. Then in cycle II increases with high enough and get good category. In the third cycle again improved even better with the end result is in good category, In cycle I, students who reach minimum score are 12 students, while students who have not get minimum score are 26 students. The average grade obtained is 68.92 with the highest score of 82 and the lowest score of 55 and the 
percentage of graduation of $31.57 \%$. The second cycle, students who passed the minimum score are 12 students, on the second cycle of students who graduated and reached minimum score increased to 31 students while students who have not fulfilled the minimum score is 7 students. The average grade obtained is 78.36 with the highest score of 88 and the lowest score 72 and the percentage of graduation is $81.57 \%$. the rate of increase in student learning outcomes continues to increase until the third cycle, which is On the third cycle of students who pass the minimum score or get a score of $\geq 75$ only reached $97.36 \%$ acquisition is almost almost achieved by all students class VII F. Researchers stop research until the third cycle based on results of data showing more than half of students have experienced significant improvements in learning outcomes.

Fourth, the use of Mind mapping method to improve student learning outcomes in social studies learning with end reflection result that is in good category. The results are also not separated in the constraints faced, both by students and teachers. The obstacles encountered are at least the main time allocation in cycle I. In addition, students' understanding of Mind Mapping is a bit slow in the sense that teachers should be more active and guide students in learning. Then the low motivation and appreciation so that if there are students who are a bit embarrassed at the time of learning took place. To overcome these obstacles need improvement efforts, teachers use active learning and effective and efficient such as the allocation of time and hours of meeting more, so that students are able to develop learning outcomes using Mind mapping method. Therefore, the researcher can conclude that this research can be deemed successful when viewed through the development of student learning in improving student learning outcomes through mind mapping method applied by the researchers and the results of post test scores obtained through the three cycles already in stage saturation in cycle III, so this research is sufficient and completed in cycle III.

\section{THANK-YOU FOR}

The authors would like to say thank you the Social Studies Education Study Program Faculty of Social Sciences Education, Indonesia University of Education, which has published this Journal Research.

\section{BIBLIOGRAPHY}

Abdul Aziz Wahab. (2012). Metode dan Model-Model Mengajar, Ilmu Pengetahuan Sosial (IPS). Bandung: Alfabeta.

Ahmad Susanto. (2014). Pengembangan Pembelajaran

IPS. Jakarta: Prenada Media.

Arikunto, S (2010). Prosedur Penelitian: Suatu

Pendekatan Praktik. Jakarta:PT.

Rineka Cipta.

Buzan, T. (2009). Buku Pintar Mind Map. Jakarta: PT

Gramedia Pustaka Utama.

Buzan, T. (2006). Gunakan Kepala Anda. Jakarta:

Interaksara.

Buzan, T. (2006). Gunakan Memori Anda. Jakarta:

Interaksara.

Dimyati dan Mudjiono. (2006). Belajar dan Pembelajaran. Jakarta: PT .Rineka Cipta.
Dwi Siswoyo. (2011). Ilmu Pendidikan. Yogyakarta: UNY Press.

Femi Olivia. (2008). Gembira Belajar dengan Mind

Mapping. Jakarta: Gramedia.

Heri Rahyubi. (2012). Teori-teori Belajar dan Aplikasi

Pembelajaran Motorik: Deskripsi dan Tinjauan Kritis. Jawa

Barat: Referens.

Komalasari, K. (2011). Pembelajaran Kontekstual Konsep dan Aplikasi. Bandung : Refika Aditama.

Nana Sudjana. (2005). Penilaian Hasil Proses Belajar

Mengajar. Bandung: PT Remaja Rosdakarya Offset.

Purwanto. (2011). Evaluasi Hasil Belajar. Yogyakarta:

Pustaka Belajar.

Porter, D, B \& Hernacki, M (2009). Quantum Learning

Membiasakan Belajar Nyaman dan Menyenangkan. Bandung:

Kaifa.

Sudjana N (2009). Penilaian Hasil Proses Belajar

Mengajar. Bandung : Remaja Rosdakarya.

Sudjana dan Rivai (2007). Teknologi Pengajaran.

Bandung: Sinar Baru.

Sapriya. (2009). Pendidikan IPS Konsep dan

Pembelajaran. Bandung: Remaja Rosdakarya.

Sapriya. (2009). Pendidikan IPS. Bandung: Rosda Karya.

Sugiyono. (2012). Metode Penelitiaian Kuantitatif,

Kuaitatif, dan $R \& D$. Bandung: Alfabeta.

Wiraatmasdja, R (2012). Metode Penelitian Tindakan

Kelas: Untuk Meningkatkankinerja guru dan dosen. Bandung:

PT Reamaja Rosdakarya offset. 